\title{
SIMULATION OF FIRE AS A FORM OF SAFETY AND PROTECTION OF HUMAN LIVES AND MATERIAL ASSETS
}

\author{
UDC 614.841
}

\section{Radoje Jevtić}

\author{
Electrotechnical School "Nikola Tesla”, Niš, Serbia
}

\begin{abstract}
Fire is one of the most dangerous occurrences in human history. Many lives have been lost in fires. Apart from human lives, a fire can destroy everything on its way-animals, vegetation, assets. Fire protection is as old as fire occurrence. The task of fire protection is to mitigate the effects of fires. The best way is, undoubtedly, fire prevention, but, if a fire occurs, fire fighting must be carried out quickly and effectively in order to save endangered humans and material properties. One of the most effective, safest and cheapest ways of fire protection is the usage of simulation software. This paper has been written to demonstrate the reasons and the advantages of simulation software usage in prediction of fire situations, fire development, fire spread all with the aim to protect human lives, animals, vegetation and material property.
\end{abstract}

Key words: fire, safety, simulation, protection

\section{INTRODUCTION}

In the history of the world, fire is one of the most dangerous phenomena which can cause damage to human life, animals, vegetation and property. In the past, fires have taken many lives and made huge material damage.

One of the first huge fires occurred in Rome, 64 A.D. According to a historian Tacitus, the duration of fire was about five days and it destroyed ten from fourteen districts in Rome. According to other historians, the Great fire of Meireki in Japan was the deadliest and most disastrous fire recorded in history. This fire occurred on March 2, in the city of Edo (1today Tokyo). The fire lasted for three days, destroyed $70 \%$ of the city and killed over 100,000 people. In 1666, in London, a huge fire destroyed central parts of London; 13,200 houses and 87 churches were destroyed, as well as homes for 70,000 residents of London (80000 residents was a total number of London's residents). Probably the worst fire that ever occurred in Germany was in Hamburg, in 1842. About 20,000 people lost their property, 51

Received September 30, 2019 / Accepted December 3, 2019

Corresponding author: Radoje Jevtić

Electrotechnical School "Nikola Tesla", Aleksandra Medvedeva 18, 18000 Niš, Serbia

E-mail: milan.jvtc@gmail.com 
lost their lives and almost a quarter of the inner part of the city was destroyed. In 1871, in Chicago, a huge fire killed more than 300 people and left 100,000 homeless. In 1987, in China, the so-called Black Dragon fire destroyed 72884 square kilometers of forest along the Amur River in China [1-5].

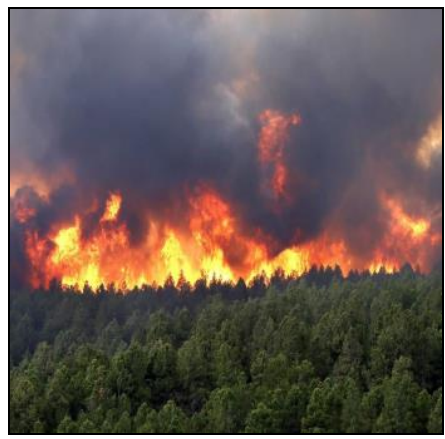

a)

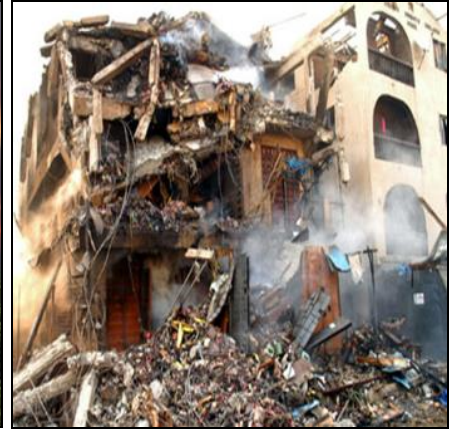

b)

Fig. 1 Huge fires in China (a), (Fig. source: https://www.lolwot.com/10-of-the-most-destructivewildfires-ever-recorded/2/) and Nigeria (b), (Fig. source: https://olorisupergal.com/2018/ 01/27/16-years-remembrance-ikeja-cantonment-bombing/)

More than three million acres of pristine forest reserves in China (about 15 million in Russia) were destroyed. In 1988, a huge fire that destroyed almost one-third of this national park happened. More than 9000 firefighters put out those fires whose costs were about 120 milion dollars. A huge fire caused by the explosion in weapon factory, in Lagos in Nigeria, on January 27, 2002, brought death to over 1000 people. At the first moment, blast attacked several square blocks and killed 300 people, mostly soldiers and members of their families. According to local sources, the strength of the explosion was so huge that windows on buildings crashed at a $15 \mathrm{~km}$ range. The scenes of fires in China and Nigeria are presented in Fig. 1 (a) and (b) [6-8].

Human negligence caused huge fire in California in 2003, where more than $1000 \mathrm{~km}^{2}$ of forest totally burned. Californian sources noted that this was the most devastating fire in state history. According to data, the space of 750043 acres burned, 3710 homes disappeared in flame and 24 people were killed including one firefighter. The fires in Greece, in 2007, lasted almost three months and were probably the worst disaster in this part of Europe. Large space, 670000 acres of forest, olive groves and farmland were totally burned.

More than one thousand houses and over 1100 other different constructions were destroyed. Many firefighters and 91 civilians were killed in this disaster. The consequence of series of fires that occurred in Australia in one day (according to some sources more than four hundred), in 2009, was 173 dead, 414 injured and 7652 relocated. This huge disaster burned more than 1.100,000 acres and destroyed 2100 homes [9, 10]. The biggest fire in Arizona history was so-called the Wallow Fire in 2011. This huge fire destroyed 841 square miles, which is about $2180 \mathrm{~km}^{2}$. Several counties were particularly d, such as Apache, Greenlee, Graham, and Navajo in Arizona and Catron County in New Mexico. Although more than 6000 people were evacuated, there were no victims. The scenes from these fires in Australia and Arizona are presented in Fig. 2 (a) and (b) [11]. The fire in northern California 
happened in November 2018 and killed 81 people, whereas the number of people listed as missing was up to 870 [12].

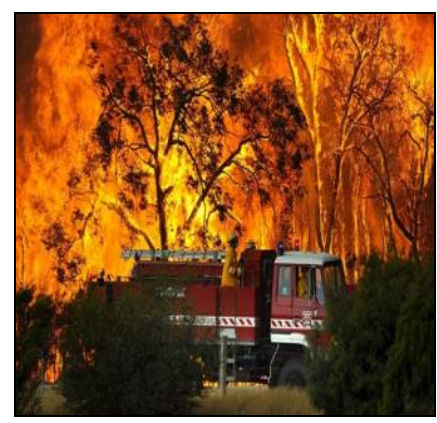

a)

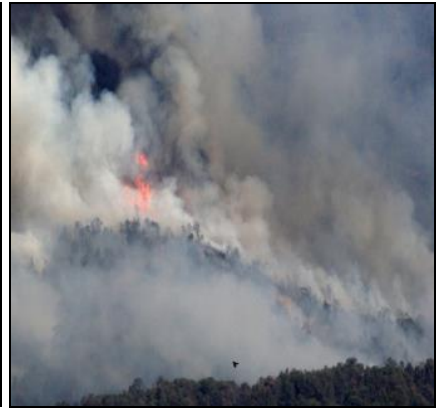

b)

Fig. 2 Huge fires in Australia (a), (Fig. source: https://www.theguardian.com/world/2009 /feb/09/australia-bush-fires-death-toll) and Arizona (b), (Fig. source: https://www.nytimes. com/2011/06/15/us/15wildfires.html)

There are different definitions of fire, but the general definition is that fire is an uncontrolled combustion process that endangers human lives and material assets. The combustion process is one of the most complex processes. This term has been variously defined across the scientific disciplines due to its physical-chemical complexity. At the early stage of scientific development, combustion was considered as a chemical process, while later it involved physical components such as mass and heat transfer, diffusion and mixture. The combustion process can be homogeneous or heterogeneous - if oxidizer and combustible material have the same state of aggregation the combustion process is homogenous, otherwise, it is heterogeneous. The oxidation process requires three different conditions: the presence of combustible material, the presence of oxidizer and the presence of an appropriate heat source. In science, this is known as a combustion triangle. For complete explanation and understanding, the fourth condition was introduced and it presents chain reaction.

Fires in objects are characterised by three different mechanisms of heat transfer: conduction, convection and radiation.

The main element in a combustion process is a combustible material. All materials can be divided into combustible and non-combustible materials. During the combustible process, combustible materials produce combustible products, heat and light energy. Non-combustible materials cannot get into combustible reaction under normal conditions. Combustion also involves heat, flame and smoke. Heat usually appears in the initial stages of combustion, while flame has a complex structure and it appears in the combustion of gasses or vapours from combustible liquids. However, smoke is a mixture of small particles of non-combusted material, ash and others that pend in gasses and vapours (carbon dioxide, carbon monoxide, water vapour, different organic vapours and other gasses and vapours) arisen in the combustion process. Dimension and structure of particles mostly depend on burning material. The dimensions of particles can be very small $(1 \mathrm{~nm}-1 \mu \mathrm{m})$, which is particularly hard to detect.

According to the above facts, it can be assumed that not every combustion is considered a fire. However, even the smallest combustion that causes damage to material properties or 
presents a threat to human lives can be defined as fire. Fire can be classified differently depending on various parameters (the class of combustible material, dimension, place, time, source place, way of detection, development phase etc.). As an example, according to the type of combustible material, fires can be divided into five different groups: A, B, C, D and E.

Class A presents fires of wood, coal, paper, cotton, flax, hemp, hay and similar materials.

Class B presents fires of liquid fuels and other flammable liquids that do not mix with water. That implies all oil derivate (gasoline, petroleum, gas oils, engine oils, different lubricating oils, and other oil modifications), carbon disulfide, different solvents, chemical diluents, lacquers, oil colours, coal-tar pitches, resins, tar, bitumen, different waxes, $t$ fats and other similar products and derivates.

Class C presents fires of gasses such as methane, propane, butane, acetylene, hydrogen and other flammable gasses.

Class D presents fires of light metals, such as magnesium, aluminium and their alloys.

Class E presents fires on different electrical devices and installations under voltage.

It is important to note that, according to some standards of other countries, there is another fire class marked as F (related to Australian classification) or K (related to American classification) and this class presents fires on different oils and fats of plant or animal origin [13-19].

One of the best, the safest and the cheapest ways of fire prevention and prediction is the usage of fire simulation software. The usage of this kind of software nowadays, with the expansion of information technologies becomes a need, not a luxury. The current market offers different software for fire simulation; however, one of the lead simulation software in this area is FDS-Fire Dynamic Simulator and its graphical environment PyroSim.

\section{FDS-FIRE DYNAMIC SIMULATOR AND PYROSIM}

"Fire Dynamics Simulator (FDS), is a computational fluid dynamics (CFD) model of fire-driven fluid flow. FDS solves numerically a form of the Navier-Stokes equations appropriate for low-speed (Ma<0.3), thermally driven flow with an emphasis on smoke and heat transport from fires. The first version of FDS was publicly released in February 2000. The first assignment of this software has been to solve different practical fire problems in fire protection engineering, while at the same time providing a tool to study fundamental fire dynamics and combustion." There were several versions of this software through its development. One of the latest versions was version 6 [20].

Pyrosim presents a special graphical environment for FDS. The main purpose is to simplify and to accelerate tasks to be done with FDS, using graphical data input instead of text processor input mode. Graphical data input mode implies the usage of 2D and 3D graphical objects; also, potential errors and mistakes are better perceived, which is very important because simulations can last from several hours to several tens of hours, even days. For instance, an accurately designed graphical object in Auto Cad could be imported into PyroSim for further analysis. PyroSim users need to have proper knowledge in thermodynamic, electronic, physic, fire protection and mathematics.

PyroSim uses MS Windows and requires at least 256 MB RAM with a graphics card that supports proper OpenGL (at least 1.1 or later) for earlier versions. For more advanced usage and the latest versions of this software, the recommendations are at least 4 GB of RAM and a graphics card with at least $512 \mathrm{MB}$ with an adequate core processor. 


\section{FIRE SIMULATION MODELS}

The first step in simulation software usage is to create a proper simulation model, in real dimensions and with real materials. This step can be done in FDS as a text file, in PyroSim as a graphic file or in some other software ( mainly AutoCAD) where a graphic file would be created and after that imported in PyroSim. After that step, it is important to set fire conditions: burner as a fire source, burner location, burner HRR (heat release rate) in $\mathrm{kW} / \mathrm{m}^{2}$, simulation duration and many other factors that contribute to the accuracy and reality of the simulation. The duration of simulation can vary and it depends on several conditions: hardware potentials of the computer on which the simulation was performed, simulation model complexity and simulation demands. For the purposes of this paper, five simulation models will be presented.

The first simulation model was the model of the Electrotechnical School "Nikola Tesla" in Niš.

Electrotechnical School "Nikola Tesla" in Niš and a proper simulation model in real dimensions from different perspectives are presented in Figures 3 and 4 ( $a$ and b).

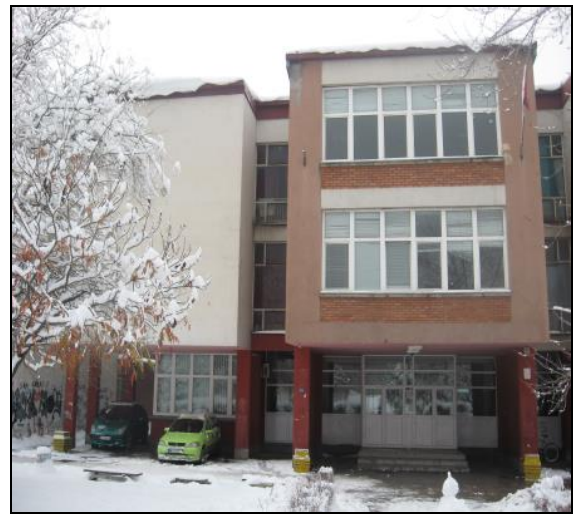

a)

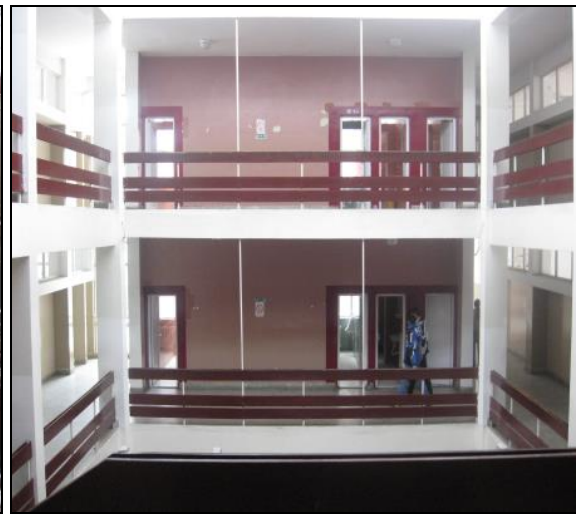

b)

Fig. 3 Electrotechnical School "Nikola Tesla" in Niš - front side (a) and the hall in classrooms part - inside (b)

Electrotechnical School "Nikola Tesla" in Niš is a secondary vocational school with more than 800 pupils and 100 employees. The approximate surface of this object is about $2542,91 \mathrm{~m}^{2}$ with a maximum height of about $12 \mathrm{~m}$. It consists of three parts: classroom part, laboratory part and a sports hall for physical education classes. On the first floor of the classrooms part there is a teachers'office, library and several offices for administrative affairs. On the second and the third floor of classroom parts, there are only classrooms and toilets of different dimensions and capacities. On the first floor of the laboratory part there are several laboratories, employee offices, staff working room, canteen and a refrigerate devices room. On the second and the third floor of the laboratory part there are only laboratories. All three parts are connected with halls and doors. 


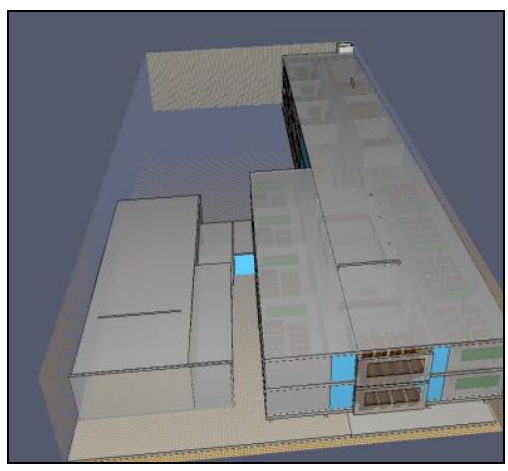

a)

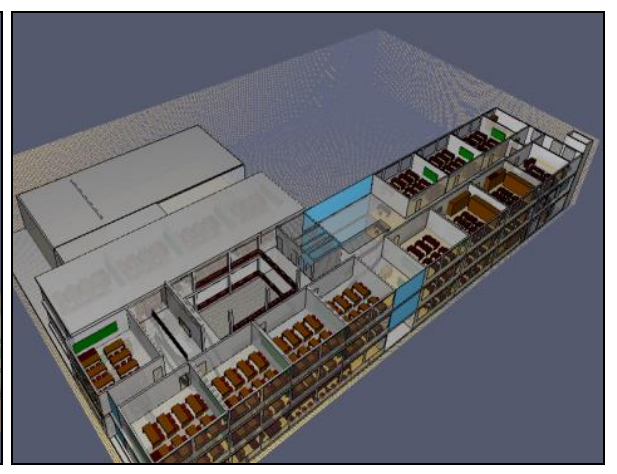

b)

Fig. 4 Different views of Electrotechnical School "Nikola Tesla" in PyroSim presentation, front side view (a) and the partial inside view from the above (b)

Beside school building exterior, it is important to create simulation models of school interior, wgich would include doors, floors, desks, chairs, cupboards and other inventory parts. Each of these parts has its own dimensions and fire characteristics (plywood, pinewood, oak wood, cardboard and similar). The total number of components used in simulation was 3949, which contributes to the complexity of the simulation model [22-24].

The second simulation model was the model of the family house. The family house used for simulation has dimensions of $10 \mathrm{~m} \times 9 \mathrm{~m} \times 5,2 \mathrm{~m}$. The house has two different floors with a height of $2.6 \mathrm{~m}$, each. The ground floor consists of a living room, kitchen, garage and pantry. The first floor has five bedrooms. The connection between the ground floor and the first floor is via stairs, while the connection between kitchen and pantry at the ground floor is a door. There was also a door between a pantry and a garage. This simulation model also contains other simulation objects such as doors, windows, beds, cabinets, desks, dressers, carpets and similar. The complete number of interior simulation objects was 36 [25].

The simulation model of the family house in real dimensions (top, bottom, front and back views) is presented in Figures 5 and 6 ( $a$ and $b$ ).

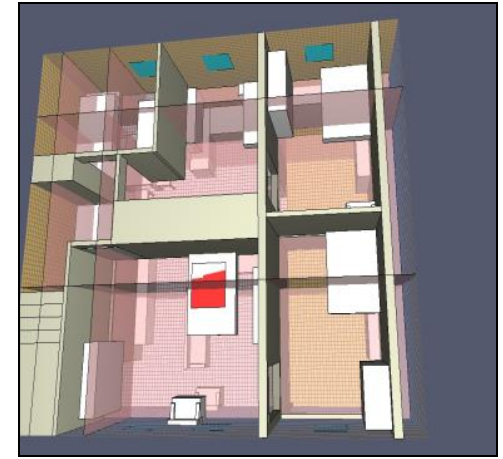

a)

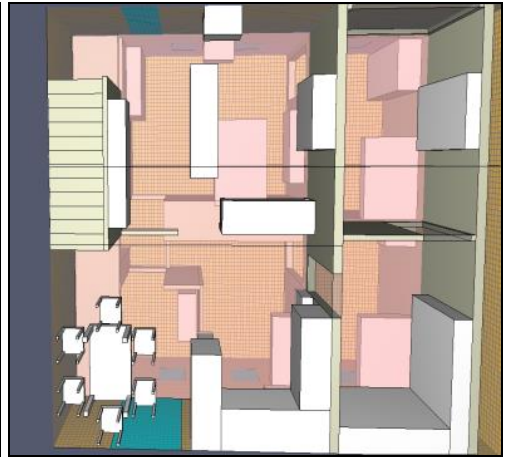

b)

Fig. 5 Simulation model of the family house, top view (a), and bottom view (b) 


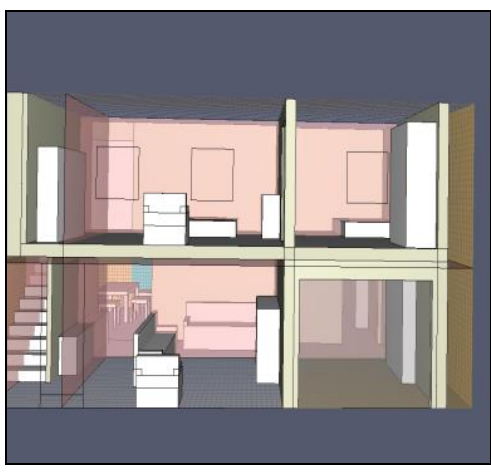

a)

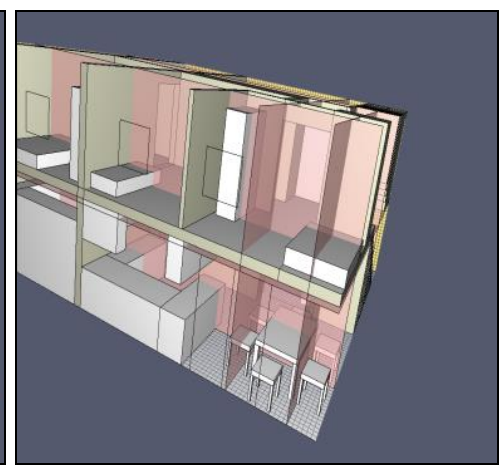

b)

Fig. 6 Simulation model of the family house, front view (a), and back view (b)

The third simulation model is the model of a building with halls and rooms. For this purpose, a building with dimensions $38.3 \mathrm{~m} \times 28.51 \mathrm{~m} \times 3.2 \mathrm{~m}$ has been used. This building has 15 different rooms with three long hallways. The walls were made from concrete with a thickness of $0.2 \mathrm{~m}$. Inside the building, there were 25 cupboards of different dimensions (width and height) made of oak wood and pinewood. There were also 8 desks and 4 chairs made of plywood and metal located in the rooms [26, 27].

Simulation model of the building with halls and rooms in real dimensions, with heat and smoke detectors arrangement, in 2D and 3D views, with positions of burners (fire source) are presented in Fig. 7 ( $a$ and $b$ ).

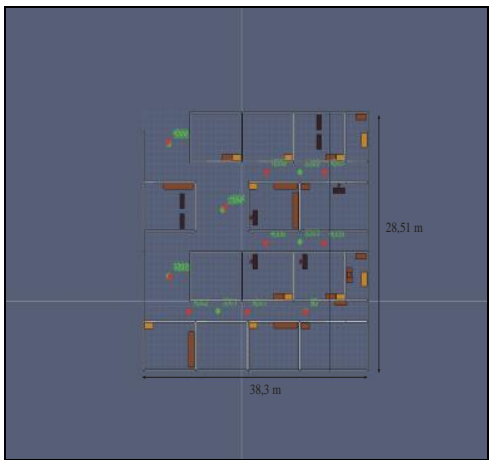

a)

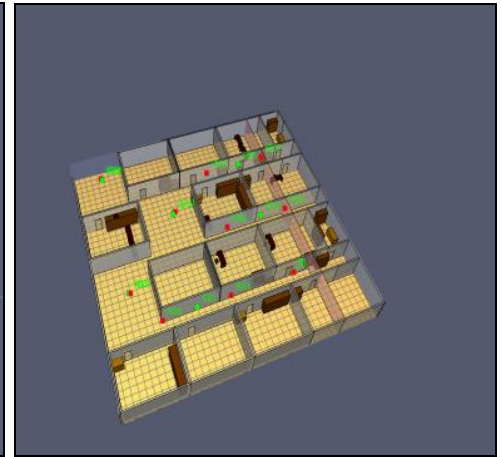

b)

Fig. 7 Burner position and heat and smoke detectors arrangement: (a) 2D simulation model of the building with halls, (b) 3D simulation model of the object with halls

The fourth simulation model was the model with dimensions of $75 \mathrm{~m}$ x $30 \mathrm{~m} \times 3.25 \mathrm{~m}$. There are five spots at which the hallways intersect. The width of every hallway was $3 \mathrm{~m}$ and there was a 0.22 -m-thick wall made of concrete between. Due to different definitions across standards, the smoke detectors' arrangement was also different [28]. 
Simulation models of a building with hallways in real dimensions, with different smoke detectors arrangement and different burner positions are presented in Fig. 8 ( $\mathrm{a}$ and b).

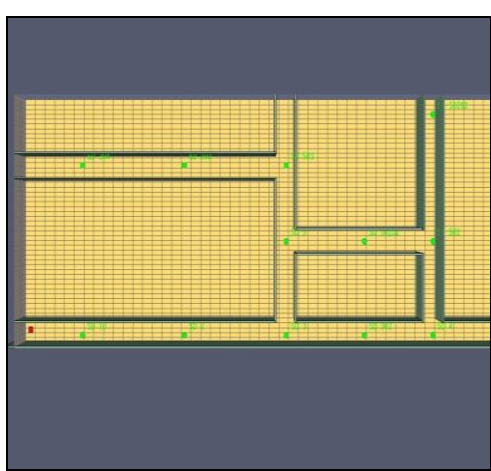

a)

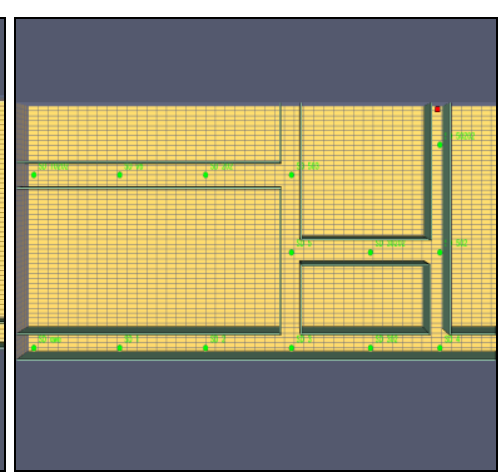

b)

Fig. 8 Simulation model of the building with halls and smoke detectors arrangement according to the EN-54 standard and a burner position (a) and smoke detectors arrangement according to the NFPA 72 standard and burner positions (b)

The fifth simulation model was the model of the residential building with occupants. Building dimensions were $20 \mathrm{~m}$ x $20 \mathrm{~m} \times 41.6 \mathrm{~m}$. The building had 16 floors, two passenger elevators, stairs between floors and fire stairs. Stairs between floors were made from concrete and their lengths were $4.687 \mathrm{~m}$, while the width of these stairs was $1.1 \mathrm{~m}$. Dimensions of stairs elements, riser and tread, were $17.9 \mathrm{~cm}$ and $28 \mathrm{~cm}$, respectively [29].

The simulation model of a high residential building, with its front and top view, is presented in Fig. 9 ( $\mathrm{a}$ and b).

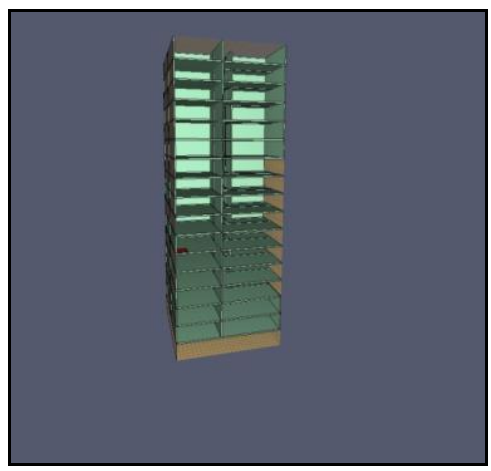

a)

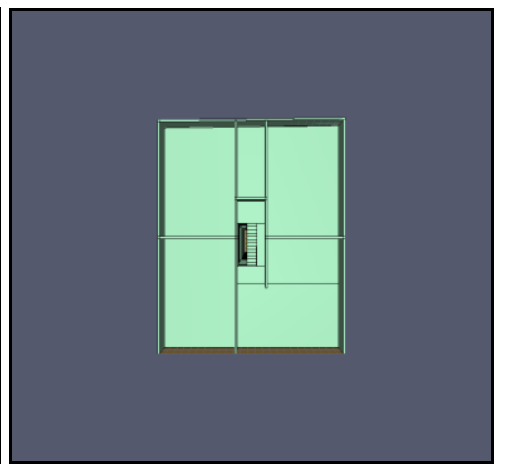

b)

Fig. 9 Simulation model of high-rise residential building, front view (a) and top view (b) 


\section{Simulation RESUltS}

Some of the simulation results for the first simulation model (fire and smoke development in the classroom on the first floor and fire development in the sports hall) are presented in Figures 10 and 11 ( $a$ and $b$ ).

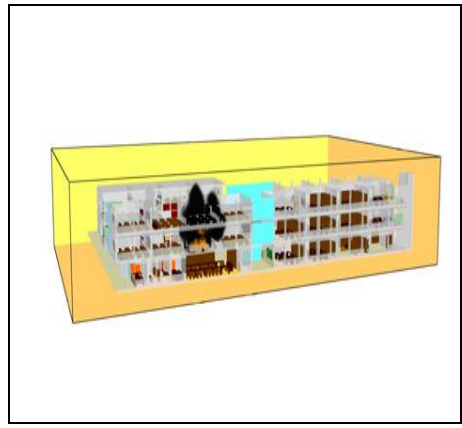

a)

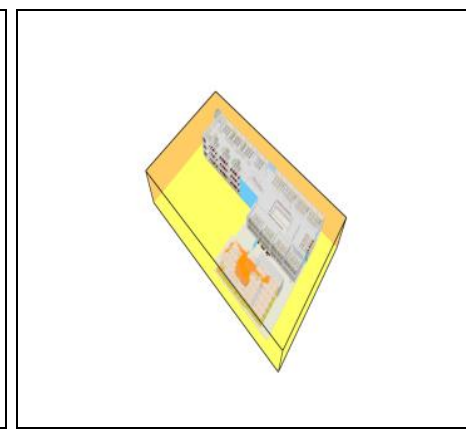

b)

Fig. 10 Simulation for the classroom on the first floor (a) and for the sports hall (b)

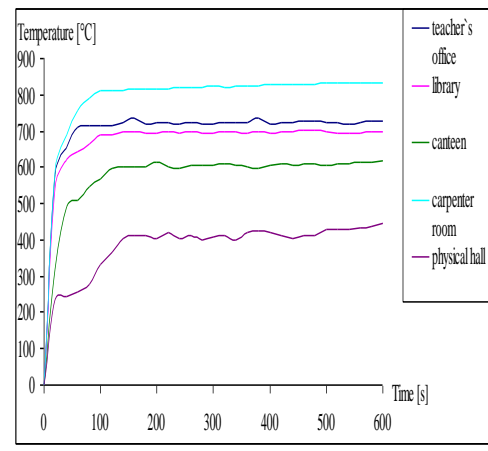

a)

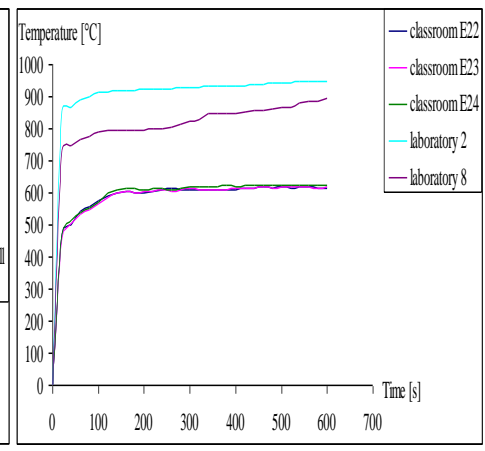

b)

Fig. 11 Simulation for rooms on the base floor (a) and simulation results for the rooms on the second floor

Some of the simulation results for the second simulation model are presented in Fig. 12 and Fig. 13 (a and b). 


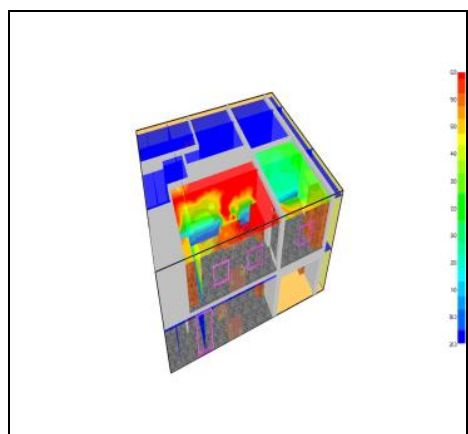

a)

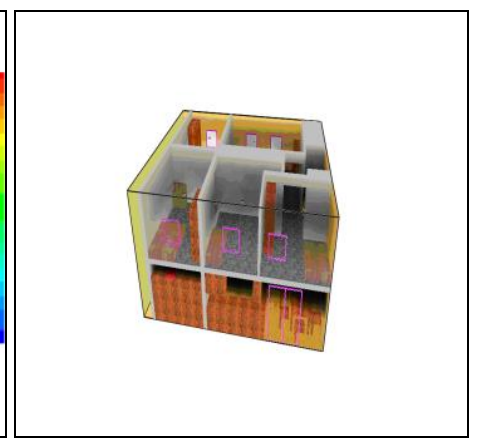

b)

Fig. 12 Thermal presentation of fire in the bedroom on the floor (a) and with smoke in the kitchen (b)

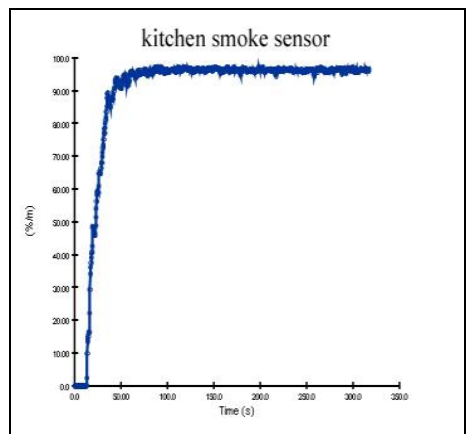

a)

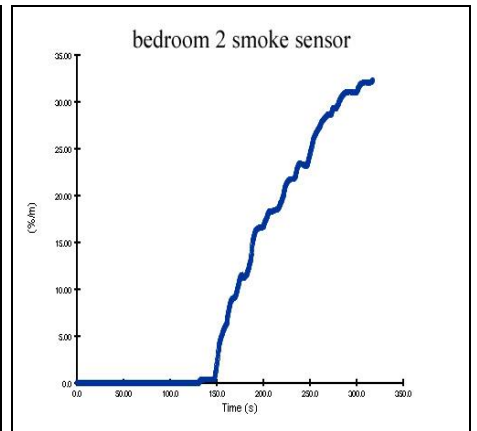

b)

Fig. 13 Simulation of smoke sensors located in the kitchen (a) and in the bedroom 2 (b)

Some of the simulation results for the third simulation model are presented in Fig. 14 and Fig. 15 (a and b).

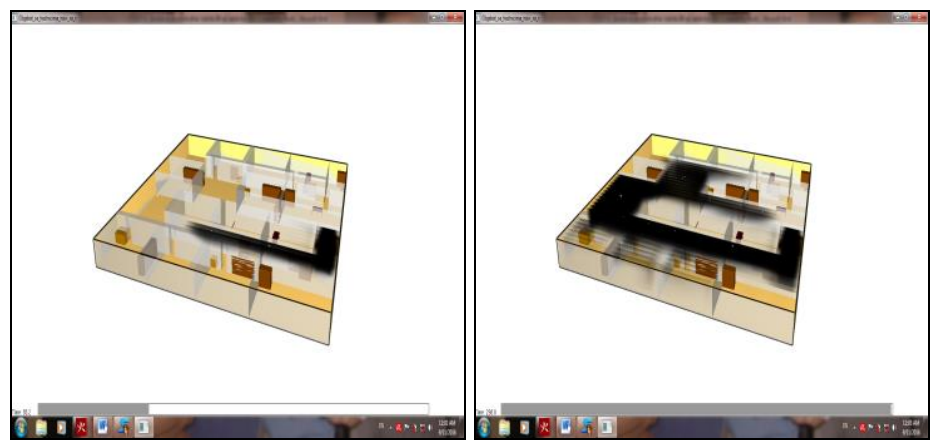

a)

b)

Fig. 14 Potential fire propagation in pantry at different moments in time, 85.2 seconds after fire start (a) and 298.8 seconds after fire start (b) 


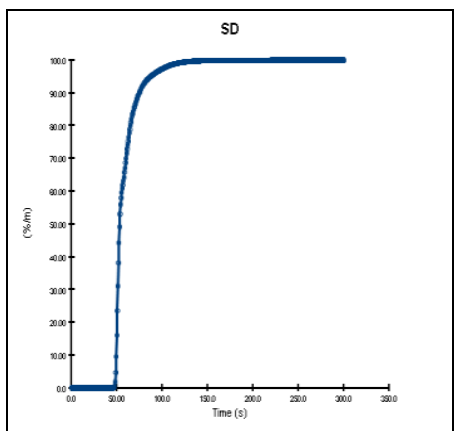

a)

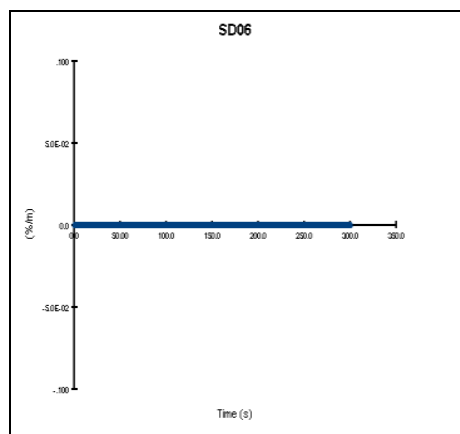

b)

Fig. 15 Simulation for the smoke detector nearest to the fire source (a) and for the smoke detector farthest from the fire source (b)

Some of the simulation results for the fourth simulation model are presented in Fig. 16 (a and $b$ ).

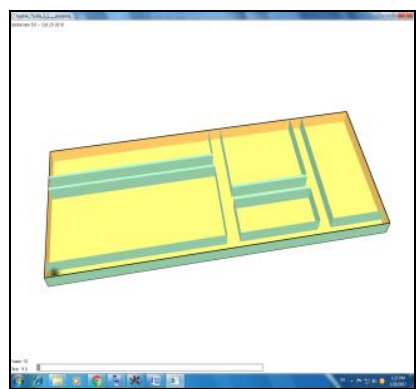

a)

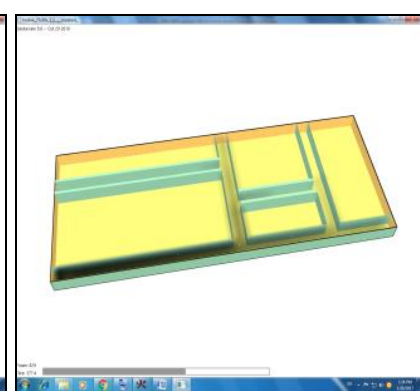

b)

Fig. 16 Potential fire propagation in a building with hallways at different moments in time, 9 seconds after fire start (a) and 377.4 seconds after fire start (b)

Some of the simulation results for the fifth simulation model are presented in Figures 17 and 18 ( $a$ and $b$ ).

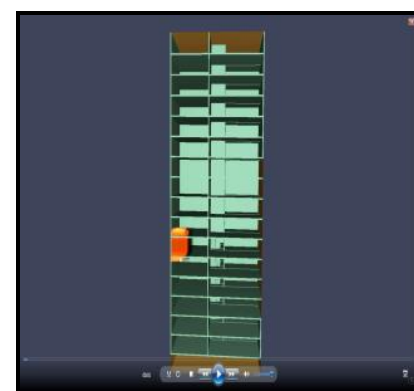

a)

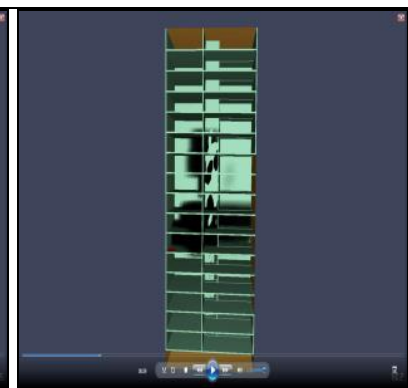

b)

Fig. 17 Fire and smoke propagation in a high-rise building after 1.6 seconds from the fire start (a) and after 60.2 seconds from the fire start (b) 


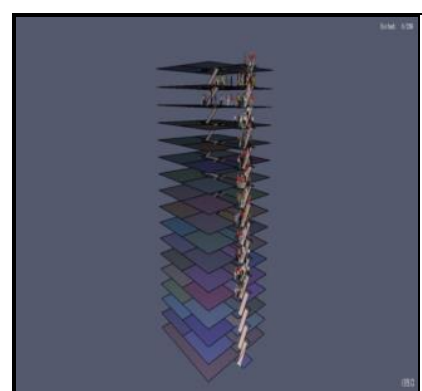

a)

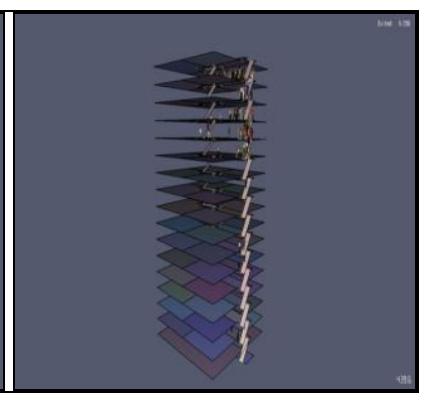

b)

Fig. 18 High-rise building evacuation for occupants who used only fire stairs for evacuation; 139 seconds after the evacuation began (a) and 439.6 seconds after the evacuation began (b) (the speed of occupants was $0.7 \mathrm{~m} / \mathrm{s}$ )

\section{THE RESULTS OF THE ANALYSIS AND THEIR SIGNIFICANCE}

The results for the first simulation model showed fire and smoke development in the chosen premises in the Electrotechnical School "Nikola Tesla" in Niš. Also, there are some results related to time and temperature dependence. The results showed that it was possible to completely predict fire and smoke in any room inside the school, as well as fire growth and smoke spreading. Based on this, it was possible to calculate the best evacuation model for pupils, teachers and other staff, and also to determinate the best access roads for fire vehicles and fire extinguishing.

The results of the second simulation model showed the potential fire and smoke spread in a family house. The investigations showed the places where a fire caused the most damage. Heat and smoke sensors, located in every room, measured temperature and smoke quantity. In addition, it was possible to perform fire simulation in all rooms with closed/open doors and windows, where the wind flow could influence fire and change smoke direction.

The results of the third simulation model showed potential fire and smoke spread in storage with several rooms and halls. It was possible to measure the time needed for the reaction of the closest detector and the time needed for all detectors positioned in storage according to the proper standard.

The results of the fourth simulation model showed the reaction times pertaining to smoke detectors that were arranged according to three different standards: EN-54, НПБ 88 and NFPA 72. It is worth mentioning that a hallway is differently defined across the standards. Reaction times for different smoke detectors arrangements were compared in different standards, which greatly influenced the determination of the best smoke detectors arrangement (in sense of the shortest reaction time, the number of needed smoke detectors, etc.). In addition, it was possible to predict fire and smoke spreading in different locations where the fire started (different locations of the burner).

The results of the fifth simulation model have great significance in terms of fire and smoke spreading, temperatures and potential evacuation ways and routes for people in high-rise residential buildings. It was possible to predict the potential fire and smoke spread and, related to those facts, to predict the best way for people to leave the building in the shortest time. The 
evacuation was analyzed in case of different evacuation routes usage: elevators, ordinary stairs or fire stairs $[30,31]$.

\section{CONCLUSION}

Simulation software is a very important tool in many engineering areas, especially in the area of fire protection. Fast and correct calculation of complex problems, great possibilities of fire prediction with the highest level of safety and cheapness are the most important advantages of this software usage. The development of simulation software is hard, complex, time-consuming and expensive, but nothing is more important than protection of human lives.

\section{REFERENCES}

1. https://www.toptenz.net/top-10-most-famous-fires-in-history.php

2. https://seanmunger.com/2015/03/02/the-night-edo-burned-the-great-fire-of-meireki/.

3. https://www.adriamedia.tv/vesti/najveci-pozari-u-istoriji-sveta-medju-njima-je-i-jedan-iz-srbije-kurirtv_92838.html.

4. https://www.thedungeons.com/hamburg/en/explore-the-dungeon/1842-the-great-fire-of-hamburg/.

5. http://www.american-historama.org/1866-1881-reconstruction-era/great-chicago-fire.htm.

6. https://list25.com/25-most-destructive-wildfires-ever-recorded-in-history/

7. https://www.npr.org/templates/story/story.php?storyId=94126845.

8. https://www.history.com/this-day-in-history/explosions-trigger-deadly-panic-in-nigeria.

9. https://list25.com/25-most-destructive-wildfires-ever-recorded-in-history/3/.

10. https://www.theguardian.com/cities/2014/feb/06/melbourne-black-saturday-fires-bushfires-2009_ anniversary

11. https://list25.com/25-most-destructive-wildfires-ever-recorded-in-history/.

12. https://www.channelnewsasia.com/news/world/california-fire-death-toll-rises-to-81-10955064.

13. Glavinić, P. and Rasković Đ. (2016); Manual for preparation of candidats for professional exam from fire protection field, Meritus tim, ISBN 978-86-917589-91, Fourth edition, Beograd, pp. 66, 67, 74, 75.

14. Blagojević, Đ. M. (2015): Alarm systems, Faculty of occupational safety in Niš, ISBN 978-86-6093-0257, Niš, pp. 48, 49, 54, 55.

15. Jevtić, R (2015); Combustion as fire consequence-great danger for human health, Zdravstvena zaštita, number 6/2015, Beograd, pp. 55-62.

16. Njekrasov, V.B. (1965): General Chemistry, Third edition, Naučna knjiga, Beograd, pp. 76, 421,460.

17. Radošević, N. (1968): Chemists and technologist handbook, Technical book, Belgrade, pp. 1168, 1269, $1285,1298,1376$.

18. Group of authors (1987), Chemistry and technology handbook-Chemical and Physical data and dimensions, Publisher working organization Rad, Belgrade, pp. 825-839, 918-922, 924.

19. Stojanović, O., Stojanović, N. and Kosanović, Đ. (1984): Chemistry and technology handbook-Harmful and hazardous materials, Publicher working organisation Rad, Belgrade, pp. 73, 93, 646, 647.

20. Kevin McGrattan, K., Hostikka, S., McDermott, R., Floyd, J. and Vanella, M. (2018). Fire Dynamics Simulator User's Guide, NIST Special Publication 1019 Sixth Edition, pp. 1., USA.

21. Thunderhead enginieering (2015): PyroSim User Manual, pp. 1-4., USA.

22. Jevtić, B. R. (2014): The importance of fire simulation in fire prediction, Tehnika Elektrotehnika, Vol. 1, Beograd, pp. 153-158.

23. Jevtić, B. R. (2015): The fire simulation as a safety advantage in fire prediction and fire protection, Safety Engineering, Vol 5., Niš, pp. 21-28.

24. Jevtić, B. R. (2017): Comparative Simulation Results forEN-54, HПБ 88 and NFPA 72 Standards-the Hallway Case, Int. Journal of Engineering Research and Application, Vol. 7.

25. Jevtić, B. R. (2016): Fire simulation in house conditions, Tehnika Elektrotehnika, Vol. 1,Beograd, pp. 160-166.Jevtić, B. R.: Fire simulation in house conditions, Tehnika Elektrotehnika, 1/2016, Beograd.

26. Jevtić, B. R., Blagojević, M. (2017): Smoke and Heat Detectors Arrangement in Hallways, Safety Engineering, Vol 7. , 2/2017, Niš, pp. 21-26. 
27. Jevtić, B. R. (2015): Selection of the fire detectors and their arrangement in object ", Bezbednost, Vol.1, Beograd, pp.197-215.

28. Jevtić, B. R. (2017): Comparative Simulation Results forEN-54, HПБ 88 and NFPA 72 Standards-the Hallway Case, Int. Journal of Engineering Research and Application, Vol. 7, pp.62-70.

29. Jevtić, B. R. (2018): Fire and evacuation in high residential buildings, Facta Universitatis, Working and Environmental Protection, Vol 15, Niš , pp. 123-134.

30. Blagojević, Đ. M. (2018): Fire protection systems designing, AGM Book, Belgrade, ISBN 978-8686363-89-3, pp. 75, 125-132, Niš.

31. Blagojević M., Radovanović R. (2010): Uloga senzora u tehničkim sistemima zaštite, Policija, bezbednost i visokotehnički kriminal - tematski zbornik, Kriminalističko-policijska akademija u Beogradu, pp. 79-96, ISSN 0354-8872, Beograd.

\section{SIMULACIJA POŽARA KAO VID BEZBEDNOSTI I ZAŠTITE LJUDSKIH ŽIVOTA I MATERIJALNIH DOBARA}

Cilj autora u ovom preglednom radu je bio da pokaže pogodnost korišćenja simulacionih programa u cilju predviđanja, stvaranja, praćenja, lokalizovanja i gasenja požara. Požar predstavlja veoma opasnu pojavu koja vrlo brzo $i$ veoma često zna da se potpuno otrgne kontroli $i$ načini nezamislive štete $u$ smislu ljudskih života, prvenstveno, a potom $i$ u smislu materijalnih dobara, biljaka, životinja $i$ životne sredine. Istorija i statistika su pokazale, koliko god bio dobar i efikasan protivpožarni sistem, da je prevencija najbolji način borbe protiv požara. Naravno da je važno i to da ukoliko dođe do požara da se isti što pre lokalizuje i eliminiše ali je uvek najbolje, gledano po svim aspektima, da do požara uopšte ne dođe ili da se požar eliminiše u početnoj fazi. Simulacioni programi su veoma važan i neizbežan alat u savremenoj borbi protiv požara. Mogućnost da se požar simulira, da se na taj način prati njegovo potencijalno širenje kao i da se ima uvid u produkte požara je svakako nešto što predstavlja nemerljivi pomak $i$ efikasnost u smislu uspešnosti, bezbednosti pa na kraju i cene kada je u putanju borba protiv požara.

Ključne reči: požar, bezbednost, simulacija, zaštita. 